\title{
Characterization of the complete mitochondrial genome of Portunus pelagicus with implications for phylogenomics
}

\author{
C.Y. Ma, H.Y. Ma, G.J. Ren, W. Wang, W. Chen, J.X. Lu, X. Zou and \\ L.B. Ma
}

East China Sea Fisheries Research Institute, Chinese Academy of Fishery Sciences, Shanghai, China

Corresponding author: L.B. Ma

E-mail: malingbo@vip.sina.com

Genet. Mol. Res. 15 (3): gmr.15038719

Received April 20, 2016

Accepted July 6, 2016

Published August 18, 2016

DOI http://dx.doi.org/10.4238/gmr.15038719

Copyright $(\subset 2016$ The Authors. This is an open-access article distributed under the terms of the Creative Commons Attribution ShareAlike (CC BY-SA) 4.0 License.

\begin{abstract}
This study determined the mitochondrial genome structure of the blue swimming crab (Portunus pelagicus), and elucidated its phylogenetic relationships among the species within the order Decapoda. The complete mitochondrial genome was $16,155 \mathrm{bp}$ long, and contained 13 protein-coding genes, 22 transfer RNA genes, 2 ribosomal RNA genes, and 1 DNA control region. The gene order of the genome was the same as that found within the family Portunidae. Twenty-three genes were on the heavy strand and 14 were on the light strand. Almost all of the protein-coding genes were initiated by an ATG codon, except for three genes (ATP6, ND1, and ND3) that started with a rare ATT codon. Of the 13 protein-coding genes, 10 ended with complete TAA or TAG stop codons and three ended with an incomplete $\mathrm{T}$ codon. Thirteen non-coding regions were identified that ranged from 1 to $30 \mathrm{bp}$ in length. Nine overlaps were found, which ranged from
\end{abstract}


1 to $7 \mathrm{bp}$ in length. Phylogenetic analyses based on 12 concatenated protein-coding genes revealed that $P$. pelagicus formed a monophyletic group with Portunus trituberculatus, which were in a larger group with Callinectes sapidus, while the genera Charybdis and Thalamita formed another group. These two groups clustered together and grouped with the genus Scylla. The phylogenetic analysis supported the inclusion of Charybdis in subfamily Portuninae of the family Portunidae, and revealed a close relationship between Charybdis and Thalamita. We suggest that Thalamita should also be classified into the subfamily Portuninae. The results can be used in the study of phylogenetic, population genetic and conservation genetics of $P$. pelagicus.

Key words: Portunus pelagicus; Mitochondrial genome; Phylogenetic relationship

\section{INTRODUCTION}

The blue crab, Portunus pelagicus, which is also known as the flower crab, is a large crab that is an excellent swimmer. In contrast with another portunid crab (Scylla serrata), this species cannot survive for long periods out of the water (Romano and Zeng, 2007a). $P$. pelagicus is found in the intertidal estuaries of the Indian and West Pacific Oceans, and is widely distributed in East Africa, Southeast Asia, East Asia, Australia, the Persian Gulf, and New Zealand (Kailola et al., 1993). It is commercially important, and is sold as a traditional hard-shell crab in the Indo-Pacific and a soft-shell crab in Asia.

Because of its growing popularity, the species has been heavily fished in recent years (Romano and Zeng, 2008; Lai et al., 2010), and is increasingly cultured. It has high potential for aquaculture because of its rapid growth rate (Josileen and Menon, 2004), ease of larviculture, high fecundity, and relatively high tolerance to nitrate and ammonia (Bryars and Havenhand, 2006; Romano and Zeng, 2007a,b,c, 2008). P. pelagicus is commercially cultivated in some areas, such as Thailand (Klinbunga et al., 2010).

Studies on this species have mainly focused on its reproductive biology (Zairion et al., 2015), embryonic and larval development, and artificial seeding (Andrés et al., 2010). Knowledge of the genetic diversity of $P$. pelagicus is essential for the conservation and aquaculture of this important crab resource, in order to construct an appropriate management scheme (Bryars and Adams, 1999). The genetic population structure of $P$. pelagicus has been investigated based on allozymes (Bryars and Adams, 1999), cytochrome oxidase subunit I (COI), microsatellite markers (Sezmis, 2004), amplified fragment length polymorphisms (Praipue et al., 2010), and random amplification of polymorphic DNA (Klinbunga et al., 2010).

The mitochondrial genome is typically a closed-circular molecule, and is approximately 14 to $18 \mathrm{~kb}$ in size. Complete mitochondrial genome sequence information is useful in studying genome-level characteristics and phylogenetic relationships (Knudsen et al., 2006), because of its high mutation rate, simple structure, abundant distribution, and maternal inheritance (Yu et al., 2012; Ma et al., 2013; Baek et al., 2014). With the development of molecular techniques, it has become easier to obtain complete mitochondrial genome sequences (Wang et al., 2015), and they have been reported in many crustacean species (Shen et al., 2007; Liu and Cui, 2010; Jondeung et al., 2012; Ma et al., 2013).

Genetics and Molecular Research 15 (3): gmr.15038719 
The purpose of this study was to report the complete mitochondrial genome of $P$. pelagicus, elucidate its evolutionary status, and estimate its population genetic diversity and differentiation. The results of this study should further our understanding of the evolutionary status and population genetic diversity of $P$. pelagicus and other related crustacean species.

\section{MATERIAL AND METHODS}

\section{Sample collection and DNA extraction}

A wild P. pelagicus individual was sampled from the southeastern coast of Guangxi, China. The crab was killed by a lethal dose of MS-222. Muscle tissues were collected from the claws and fixed in 99\% ethanol at room temperature. Genomic DNA was extracted according to the protocol described by Ma et al. (2009).

\section{Primers, polymerase chain reaction (PCR), and sequencing}

First, the partial sequences of four P. pelagicus genes (12S rRNA, 16S rRNA, Cytb, and $C O I$ ) and the complete mitochondrial genomes of three other crab species (Charybdis japonica, Scylla paramamosain, and Portunus trituberculatus) were downloaded from the GenBank database. The four genes were amplified, resequenced, and confirmed. The complete mitochondrial genome of P. pelagicus was then obtained by overlapping PCR and sequencing.

The total PCR volume was $25 \mu \mathrm{L}$, which contained $0.4 \mu \mathrm{M}$ each primer, $0.2 \mathrm{mM}$ each dNTP, 1X PCR buffer, $1.5 \mathrm{mM} \mathrm{MgCl}, 0.75 \mathrm{U}$ Taq polymerase, and $100 \mathrm{ng}$ template DNA. The thermocycler conditions were as follows: an initial denaturation at $94^{\circ} \mathrm{C}$ for $4 \mathrm{~min}$; then 37 cycles of $30 \mathrm{~s}$ at $94^{\circ} \mathrm{C}, 50 \mathrm{~s}$ at a primer-specific annealing temperature, and $50 \mathrm{~s}$ at $72^{\circ} \mathrm{C}$. Finally, the products were extended for $7 \mathrm{~min}$ at $72^{\circ} \mathrm{C}$. The amplification products were separated on $1.5 \%$ agarose gels (TaKaRa, China), and directly sequenced in both directions using an ABI PRISM ${ }^{\circledR} 3730$ Automated DNA Sequencer (PE Corporation). The sequences obtained were edited and assembled by EditSeq and SeqMan (DNASTAR).

\section{Complete mitochondrial genome analysis}

A graphical map of the complete mitochondrial genome was drawn using the online software OrganellarGenomeDRAW (http://ogdraw.mpimp-golm.mpg.de/) (Lohse et al., 2007). The genome structure of $P$. pelagicus was determined based on those of the closely related species S. paramamosain (Ma et al., 2013) and C. japonica (Liu and Cui, 2010). Transfer RNAs (tRNAs) were identified by their proposed clover-leaf secondary structure and their anticodons using the web-based tRNA-scanSE 1.21 program (http://lowelab.ucsc. edu/tRNAscan-SE/) (Lowe and Eddy, 1997), with the default search mode set. MEGA 4.0 was used to determine the nucleotide composition of the mitochondrial genome, and translate protein-coding genes into amino acids according to codon usage (Kumar et al., 2008). Finally, the complete mitochondrial genome DNA sequence was submitted to the GenBank database using the software Sequin 12.30 (http://www.ncbi.nlm.nih.gov/Sequin/).

\section{Phylogenomic analysis}

The complete mitochondrial genomes of 22 Decapoda species were downloaded for

Genetics and Molecular Research 15 (3): gmr.15038719 
phylogenetic analysis from the GenBank database, and one species (Harpiosquilla harpax) was used as an outgroup taxon.

The 13 protein-coding genes were aligned by ClustalW in MEGA 4.0 with the default settings; however, the gene ND6 was excluded because of its high heterogeneity, which may cause poor phylogenetic performance (Miya and Nishida, 2000). The remaining 12 protein-coding gene sequences were linked to construct sequence alignments. The sequence alignments were then formatted and analyzed using RAxML web servers (http://embnet.vitalit.ch/raxml-bb/index.php) (Stamatakis et al., 2008). The evolutionary rates of the 12 proteincoding genes were estimated using the CAT model, and a maximum likelihood search was conducted after bootstrapping. Finally, the phylogenetic tree was viewed and edited using the software FigTree v1.4.2.

\section{RESULTS AND DISCUSSION}

\section{Genome organization}

The P. pelagicus mitochondrial genome was a typical, circular molecule that was 16,155 bp in length (GenBank accession No. KT382858), and consisted of 13 protein-coding genes, 22 tRNA genes, 2 ribosomal RNA genes, and 1 DNA control region (Figure 1).

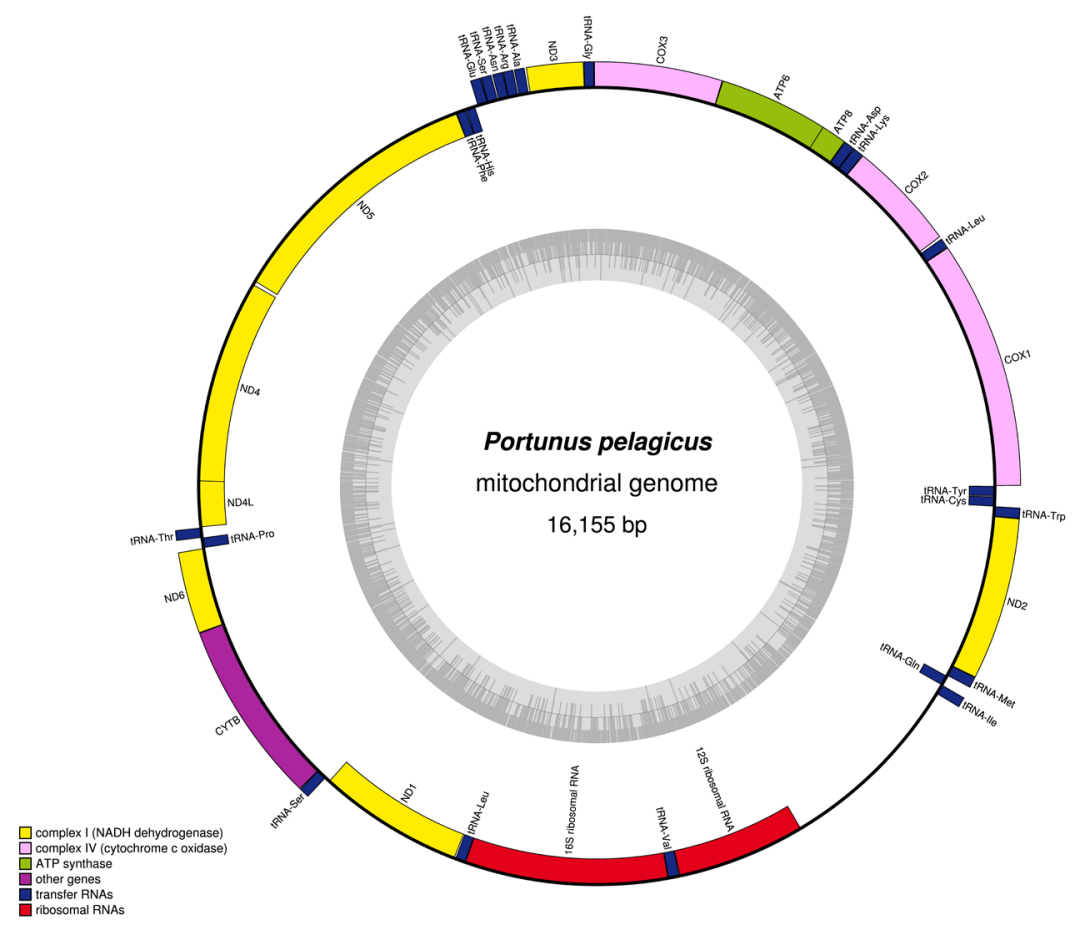

Figure 1. Complete mitochondrial genome of Portunus pelagicus. Genes encoded by the heavy strand are shown outside the circle and those encoded by the light strand are shown inside the circle. The inner ring shows the GC content of the genome.

Genetics and Molecular Research 15 (3): gmr.15038719 
Twenty-three genes were located on the heavy strand and 14 were on the light strand. All of the protein-coding genes were initiated by an ATG codon, except three genes (ATP6, $N D 1$, and ND3), which started with a rare ATT codon. Of the 13 protein-coding genes, 10 ended with complete TAA or TAG stop codons and three ended with an incomplete T codon (Table 1). The lengths of the control regions in the 12 species ranged from 514 to $1435 \mathrm{bp}$.

Table 1. Genetic structure of the mitochondrial genome of Portunus pelagicus.

\begin{tabular}{|c|c|c|c|c|c|c|c|c|}
\hline \multirow[t]{2}{*}{ Gene } & \multicolumn{2}{|c|}{ Position } & \multirow[t]{2}{*}{ Size (bp) } & \multicolumn{3}{|c|}{ Codon } & \multirow[t]{2}{*}{ Intergenic nucleotide $(\mathrm{bp})^{\mathrm{b}}$} & \multirow[t]{2}{*}{ Strand $^{\mathrm{c}}$} \\
\hline & From & To & & Amino acid & Start & Stop $^{\mathrm{a}}$ & & \\
\hline $\mathrm{COI}$ & 1 & 1,534 & 1,534 & 511 & ATG & T- & 0 & $\mathrm{H}$ \\
\hline$t R N A^{\text {Leu }(U U R)}$ & 1,535 & 1,599 & 65 & & & & 12 & $\mathrm{H}$ \\
\hline COII & 1,612 & 2,296 & 685 & 228 & ATG & T- & 0 & $\mathrm{H}$ \\
\hline$t R N A^{L y s}$ & 2,297 & 2,363 & 67 & & & & 0 & $\mathrm{H}$ \\
\hline$t R N A^{A s p}$ & 2,364 & 2,431 & 68 & & & & 0 & $\mathrm{H}$ \\
\hline ATP8 & 2,432 & 2,593 & 162 & 53 & ATG & TAG & -7 & $\mathrm{H}$ \\
\hline ATP6 & 2,587 & 3,264 & 678 & 225 & ATT & TAA & -1 & $\mathrm{H}$ \\
\hline COIII & 3,264 & 4,055 & 792 & 263 & ATG & TAA & -1 & $\mathrm{H}$ \\
\hline$t R N A^{G l y}$ & 4,055 & 4,118 & 64 & & & & 0 & $\mathrm{H}$ \\
\hline ND3 & 4,119 & 4,472 & 354 & 117 & ATT & TAG & 8 & $\mathrm{H}$ \\
\hline$t R N A^{A l a}$ & 4,481 & 4,545 & 65 & & & & 4 & $\mathrm{H}$ \\
\hline$t R N A^{A r g}$ & 4,550 & 4,614 & 65 & & & & 0 & $\mathrm{H}$ \\
\hline$t R N A^{A s n}$ & 4,615 & 4,680 & 66 & & & & 5 & $\mathrm{H}$ \\
\hline$t R N A^{\operatorname{Ser}(A G N)}$ & 4,686 & 4,752 & 67 & & & & 0 & $\mathrm{H}$ \\
\hline$t R N A^{\text {Glu }}$ & 4,753 & 4,819 & 67 & & & & 19 & $\mathrm{H}$ \\
\hline$t R N A^{H i s}$ & 4,839 & 4,901 & 63 & & & & 1 & $\mathrm{~L}$ \\
\hline$t R N A^{\text {Phe }}$ & 4,903 & 4,966 & 64 & & & & -1 & $\mathrm{~L}$ \\
\hline ND5 & 4,966 & 6,693 & 1,728 & 575 & ATG & TAA & 20 & $\mathrm{~L}$ \\
\hline$N D 4$ & 6,714 & 8,048 & 1,335 & 444 & ATG & TAG & -7 & $\mathrm{~L}$ \\
\hline$N D 4 L$ & 8,042 & 8,344 & 303 & 100 & ATG & TAA & 2 & $\mathrm{~L}$ \\
\hline$t R N A^{T h r}$ & 8,347 & 8,411 & 65 & & & & 0 & $\mathrm{H}$ \\
\hline$t R N A^{\text {Pro }}$ & 8,412 & 8,479 & 68 & & & & 2 & $\mathrm{~L}$ \\
\hline ND6 & 8,482 & 8,988 & 507 & 168 & ATG & TAA & -1 & $\mathrm{H}$ \\
\hline$C y t b$ & 8,988 & 10,122 & 1,135 & 378 & ATG & T- & 0 & $\mathrm{H}$ \\
\hline$t R N A^{\operatorname{Ser}(U C N)}$ & 10,123 & 10,189 & 67 & & & & 30 & $\mathrm{H}$ \\
\hline$N D 1$ & 10,220 & 11,176 & 957 & 318 & ATT & TAA & 5 & $\mathrm{~L}$ \\
\hline$t R N A^{\operatorname{Leu}(C U N)}$ & 11,182 & 11,250 & 69 & & & & 0 & $\mathrm{~L}$ \\
\hline $16 S r R N A$ & 11,251 & 12,580 & 1,330 & & & & 0 & $\mathrm{~L}$ \\
\hline$t R N A^{\text {Val }}$ & 12,581 & 12,654 & 74 & & & & 0 & $\mathrm{~L}$ \\
\hline $12 S r R N A$ & 12,655 & 13,500 & 846 & & & & 0 & $\mathrm{~L}$ \\
\hline Control region & 13,501 & 14,745 & 1,245 & & & & 0 & \\
\hline$t R N A^{\text {Ile }}$ & 14,746 & 14,812 & 67 & & & & -3 & $\mathrm{H}$ \\
\hline$t R N A^{G \ln }$ & 14,810 & 14,878 & 69 & & & & 3 & $\mathrm{~L}$ \\
\hline$t R N A^{M e t}$ & 14,882 & 14,950 & 69 & & & & 0 & $\mathrm{H}$ \\
\hline ND2 & 14,951 & 15,958 & 1,008 & 335 & ATG & TAG & -2 & $\mathrm{H}$ \\
\hline$t R N A^{T r p}$ & 15,957 & 16,023 & 67 & & & & -1 & $\mathrm{H}$ \\
\hline$t R N A^{C y s}$ & 16,023 & 16,087 & 65 & & & & 2 & $\mathrm{~L}$ \\
\hline$t R N A^{T y r}$ & 16,090 & 16,155 & 66 & & & & 0 & $\mathrm{~L}$ \\
\hline
\end{tabular}

${ }^{\mathrm{a}} \mathrm{T}$ - represents incomplete stop codons; ${ }^{\mathrm{b}}$ Numbers correspond to the nucleotides separating adjacent genes. Negative numbers indicate overlapping nucleotides; ${ }^{\mathrm{C}} \mathrm{H}$ or $\mathrm{L}$ indicates that the gene was encoded by the heavy or light strand, respectively.

The length of the control region was $1245 \mathrm{bp}$, which was shorter than that in Callinectes sapidus but longer than that in other crab species under Decapoda (Table 2).

The lengths of other regions of the mitochondrial genome were approximately the same among these species. The mitochondrial genome lengths of most crab species sequenced in the Decapoda were slightly different, mainly due to the differing sizes of the control region. The gene arrangement and order was the same as that found within the family Portunidae, such as that in C. japonica (Liu and Cui, 2010) and S. paramamosain (Ma et al., 2013). However, $t R N A^{H i s}$ was between NAD4 and NAD5, which is different to that in Charybdis feriata but the 
same as that in most arthropods (Table 1). Different gene rearrangements in the mitochondrial genome is relatively common in crustacean species (Shen et al., 2007), and are probably caused by slipped-strand mispair and gene deletions (Yamauchi et al., 2003).

\begin{tabular}{|c|c|c|c|c|c|c|c|c|c|c|c|c|c|}
\hline \multirow[t]{2}{*}{ Species } & \multirow{2}{*}{$\begin{array}{l}\text { GenBank } \\
\text { accession No. }\end{array}$} & \multicolumn{2}{|c|}{ Heavy strand } & \multicolumn{2}{|c|}{13 protein-coding g genes } & \multicolumn{2}{|c|}{$16 S r R N A$} & \multicolumn{2}{|c|}{$12 S \mathrm{rRNA}$} & \multicolumn{2}{|c|}{22 transfer RNA genes } & \multicolumn{2}{|c|}{ Control region } \\
\hline & & \begin{tabular}{|l} 
Length (bp) \\
\end{tabular} & $\mathrm{A}+\mathrm{T}(\%)$ & \begin{tabular}{|l|} 
No. of amino acids \\
\end{tabular} & $\mathrm{A}+\mathrm{T}(\%)$ & Length (bp) & $\mathrm{A}+\mathrm{T}(\%)$ & \begin{tabular}{|l|} 
Length (bp) \\
\end{tabular} & $\mathrm{A}+\mathrm{T}(\%)$ & \begin{tabular}{|l|} 
Length (bp) \\
\end{tabular} & $\mathrm{A}+\mathrm{T}(\%)$ & Length (bp) & $\mathrm{A}+\mathrm{T}(\%)$ \\
\hline $\begin{array}{l}\text { Portunus pelagicus } \\
\text { Pot }\end{array}$ & KT382858 & 16,155 & 68.72 & 3,715 & 66.79 & 1,330 & 73.31 & 846 & 69.62 & 1,467 & 71.57 & 1,245 & 76.22 \\
\hline Portunus trituberculatus & AB093006 & 16,026 & 70.20 & 3,715 & 68.80 & 1,332 & 73.80 & 840 & 70.10 & 1,468 & 72.00 & 1,104 & 76.30 \\
\hline Charybdis feriata & \begin{tabular}{|l|l|} 
KF386147 \\
\end{tabular} & 15,660 & 70.15 & 3,716 & 68.60 & 1,321 & 74.26 & 843 & 71.89 & 1,473 & 71.76 & 762 & 78.74 \\
\hline Charybdis japonica & \begin{tabular}{|l|l|} 
FJ460517 \\
\end{tabular} & 15,738 & 69.20 & 3,712 & 67.80 & 1,317 & 74.20 & 834 & 70.30 & 1,458 & 70.90 & 863 & 74.70 \\
\hline Scylla tranquebarica & \begin{tabular}{|l|l|} 
NC 012567 \\
\end{tabular} & 15,833 & 73.80 & $\begin{array}{l}3,716 \\
3,716\end{array}$ & 72.00 & 1,339 & 77.10 & 869 & 75.90 & $\begin{array}{l}1,486 \\
1,486\end{array}$ & 74.40 & 854 & 86.50 \\
\hline Scylla olivacea & NC_012569 & 15,723 & 69.40 & 3,715 & 67.30 & 1,337 & 74.40 & 852 & 72.40 & 1,482 & 72.30 & 778 & 79.00 \\
\hline 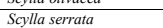 & \begin{tabular}{|l|} 
HM590866 \\
\end{tabular} & $\frac{15,721}{15,721}$ & 69.22 & $\frac{3,1714}{3,714}$ & 69.20 & 1,337 & 74.50 & 839 & 71.80 & $\begin{array}{l}1,402 \\
, 478\end{array}$ & 72.26 & 788 & 79.10 \\
\hline Scylla paramamosain & \begin{tabular}{|l|l|} 
JX457150 \\
\end{tabular} & 15,824 & 73.04 & 3,715 & 70.88 & 1,340 & 77.46 & 869 & 75.72 & 1,482 & 74.56 & 833 & 86.67 \\
\hline Callinectes sapidus & \begin{tabular}{|l|} 
NC 006281 \\
\end{tabular} & 16,263 & 69.10 & 3,712 & 67.00 & 1,323 & 71.80 & 785 & 70.30 & 1,463 & 71.60 & 1,435 & 78.20 \\
\hline Eriocheir sinensis & NC_006992 & 16,354 & 71.70 & 3,718 & 68.90 & 1,311 & 77.40 & 899 & 76.60 & 1,473 & 72.40 & 896 & 83.10 \\
\hline 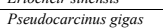 & \begin{tabular}{|l|} 
NC 006891 \\
\end{tabular} & $\frac{10,535}{15,515}$ & 70.50 & 3,734 & 68.80 & 1,324 & 74.90 & 821 & 73.80 & $\frac{1,473}{1,460}$ & 73.20 & 593 & 80.30 \\
\hline Geothelphusa dehaani & \begin{tabular}{|l|l|} 
NC_ 007379 \\
\end{tabular} & 18,197 & 74.90 & 3,711 & 71.50 & 1,315 & 77.10 & 821 & 76.40 & 1,519 & 75.80 & 514 & 87.20 \\
\hline
\end{tabular}

Nine 1- to 7-bp overlaps and 13 intergenic spacers that were between 1 and $30 \mathrm{bp}$ in length were found, which in general is similar to that reported in other species' mitochondrial genomes (Ma et al., 2013; Baek et al., 2014; Wang et al., 2014). The A + T contents of the different regions ranged from $66.79 \%$ (protein-coding region) to $76.22 \%$ (control region), and the overall A + T content was $68.72 \%$, which is similar to that in C. japonica, Scylla olivacea, and S. serrata (Table 2).

\section{Protein-coding genes}

A total of 13 protein-coding genes were identified, which were $11,178 \mathrm{bp}$ in length and coded 3715 amino acids. ATP8 had the highest A + T content $(72.84 \%)$ and COIII the lowest $(63.36 \%)$ (Table 2). Four protein-coding genes (ND1, ND4, ND4L, and ND5) were encoded by the light strand, and the other nine (COI, COII, COIII, APT6, ATP8, ND2, ND3, $N D 6$, and $C y t b)$ were encoded by the heavy strand. All 13 genes were initiated by two types of start codon (ATG and ATT) (Table 1). Nine protein-coding genes (ATP6, ATP8, ND1, $N D 2, N D 3, N D 4, N D 4 L, N D 5$, and $N D 6$ ) ended with a typical stop codon (TAA or TAG), whereas an incomplete stop codon (T-) was detected in the remaining four genes (COI, COII, $C O I I I$, and $C y t b$ ). Variable start codons and incomplete stop codons exist in the mitochondrial genomes of many species (Ma et al., 2013, 2015). In the mitochondrial genome of Myrmeleon immanis, four types of start codons have been detected (Yan et al., 2014). Two incomplete stop codons have been found in the C. feriata mitochondrial genome (Ma et al., 2015), and one was detected in the S. paramamosain mitochondrial genome (Ma et al., 2013). Post-transcriptional polyadenylation may result in an incomplete stop codon (Ojala et al., 1981).

\section{Transfer and ribosomal RNA genes}

A total of 22 tRNA genes were identified, which ranged in size from 63 to $74 \mathrm{bp}$. The total length of the tRNA genes was $1467 \mathrm{bp}$. The average A + T content of the 22 tRNA genes was $71.57 \%$, with the highest content in $t R N A^{T h r}(78.46 \%)$ and the lowest in $t R N A^{L y s}(59.70 \%)$. They could all be folded into a typical clover-leaf secondary structure, as in C. feriata (Figure 2). Because of a lack of dihydrouracil arms, $t R N A^{\operatorname{Ser}(A G N)}$ cannot form a secondary structure in C. japonica and S. paramamosain (Liu and Cui, 2010; Ma et al., 2013). As in some closely related crabs, 14 tRNA genes were located on the heavy strand and the others were located on the light strand. The length of the aminoacyl stem in all of the tRNA genes was $7 \mathrm{bp}$. The

Genetics and Molecular Research 15 (3): gmr.15038719 
anticodon loop was $7 \mathrm{bp}$ long in all of the tRNA genes, except for $t R N A^{\operatorname{Ser}(U C N)}$. Seventeen unmatched base pairs were detected in the 22 tRNA genes, which is more than that found in the tRNA genes of $C$. feriata (Ma et al., 2015).

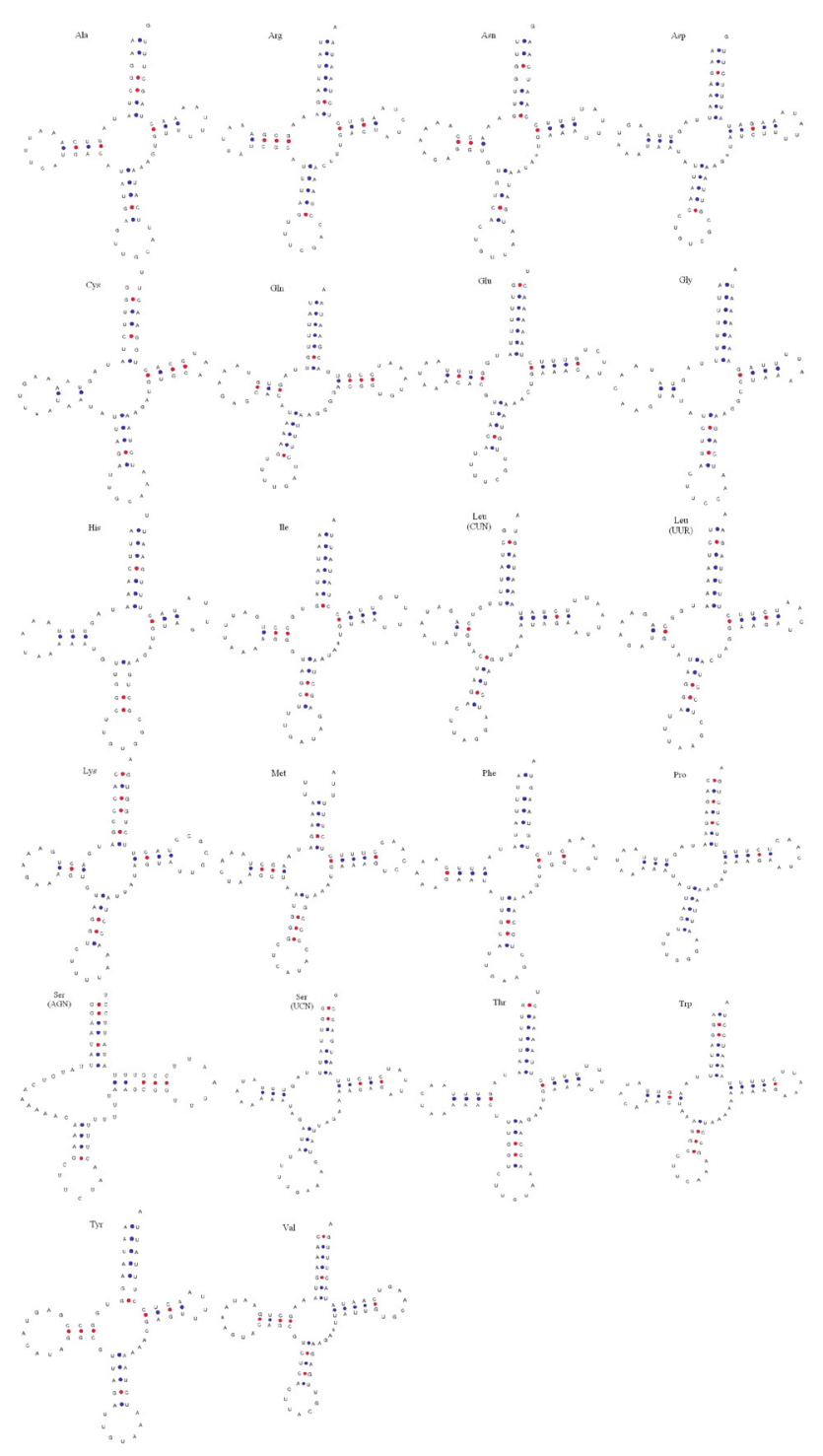

Figure 2. Putative secondary structures of 22 transfer RNAs detected in the mitochondrial genome of Portunus pelagicus.

As in related species, both $16 S$ rRNA and $12 S r R N A$ were located on the light strand of the mitochondrial genome. $16 S r R N A$ and $12 S r R N A$ were 1330 and 846 bp long, respectively, and their $\mathrm{A}+\mathrm{T}$ contents were 73.31 and $69.62 \%$, respectively. They were located between $t R N A^{\operatorname{Leu}(C U N)}$ and the control region, and were separated by $t R N A^{V a l}$.

Genetics and Molecular Research 15 (3): gmr.15038719 


\section{Non-coding regions}

The putative control region was located between $12 S$ rRNA and $t R N A^{I l e}$, and was the main non-coding region (1245 bp in length). The nucleotide composition of the control region was $42.08 \%$ for $\mathrm{A}, 9.80 \%$ for $\mathrm{G}, 34.14 \%$ for $\mathrm{T}$, and $13.98 \%$ for $\mathrm{C}$ (Table 3 ). A and T were very abundant, which resulted in a high $\mathrm{A}+\mathrm{T}$ content. The $\mathrm{A}+\mathrm{T}$ content was higher $(76.22 \%)$ than that of other regions in the mitochondrial genome, as in other crab species (Table 3). In addition, the microsatellite sequences (TA $)_{3},(\mathrm{AT})_{3},(\mathrm{TA})_{4},(\mathrm{AT})_{4}$, and (TA) $)_{11}$ were detected. Microsatellites have also been identified in the control region of the Nymphes myrmeleonoides mitochondrial genome (Yan et al., 2014). Twelve other non-coding regions were identified, which ranged from 1 to $30 \mathrm{bp}$ in length.

Table 3. Base compositions of different regions of the mitochondrial genome of Portunus pelagicus.

\begin{tabular}{|c|c|c|c|c|c|}
\hline \multirow[t]{2}{*}{ Region* } & \multicolumn{4}{|c|}{ Base composition (\%) } & \multirow{2}{*}{$\mathrm{A}+\mathrm{T}$ content $(\%)$} \\
\hline & $\mathrm{A}$ & $\mathrm{G}$ & $\mathrm{T}$ & $\mathrm{C}$ & \\
\hline \multicolumn{6}{|l|}{ Protein-coding genes } \\
\hline $\mathrm{COI}$ & 26.34 & 16.17 & 37.35 & 20.14 & 63.69 \\
\hline COII & 29.34 & 15.33 & 34.01 & 21.31 & 63.36 \\
\hline ATP8 & 30.25 & 10.49 & 42.59 & 16.67 & 72.84 \\
\hline ATP6 & 28.17 & 12.24 & 38.50 & 21.09 & 66.67 \\
\hline COIII & 27.27 & 14.65 & 37.12 & 20.96 & 64.39 \\
\hline ND3 & 27.68 & 12.71 & 37.29 & 22.32 & 64.97 \\
\hline ND5 & 39.58 & 11.05 & 29.92 & 19.44 & 69.50 \\
\hline ND4 & 40.82 & 11.24 & 29.21 & 18.73 & 70.04 \\
\hline ND4L & 40.59 & 10.56 & 25.41 & 23.43 & 66.01 \\
\hline ND6 & 24.46 & 10.06 & 45.36 & 20.12 & 69.82 \\
\hline$C y t b$ & 25.99 & 14.36 & 38.41 & 21.23 & 64.41 \\
\hline NDI & 42.53 & 11.39 & 24.45 & 21.63 & 66.98 \\
\hline ND2 & 26.39 & 10.42 & 41.37 & 21.83 & 67.76 \\
\hline \multicolumn{6}{|l|}{ tRNA genes } \\
\hline$t R N A^{\text {Leu }(U U R)}$ & 36.92 & 18.46 & 30.77 & 13.85 & 67.69 \\
\hline$t R N A^{L y s}$ & 28.36 & 20.90 & 31.34 & 19.40 & 59.70 \\
\hline$t R N A^{A s p}$ & 38.24 & 13.24 & 39.71 & 8.82 & 77.94 \\
\hline tRNA & 42.19 & 10.94 & 34.38 & 12.50 & 76.56 \\
\hline tRNA $A^{A l a}$ & 33.85 & 16.92 & 36.92 & 12.31 & 70.77 \\
\hline$t R N A^{A r g}$ & 35.38 & 12.31 & 35.38 & 16.92 & 70.77 \\
\hline$t R N A^{A s n}$ & 36.36 & 18.18 & 34.85 & 10.61 & 71.21 \\
\hline$t R N A^{\operatorname{Ser}(A G N)}$ & 31.34 & 14.93 & 40.30 & 13.43 & 71.64 \\
\hline$t R N A^{\text {Glu }}$ & 32.84 & 13.43 & 40.30 & 13.43 & 73.13 \\
\hline$t R N A^{H i s}$ & 38.10 & 7.94 & 33.33 & 20.63 & 71.43 \\
\hline tRNA $A^{\text {Phe }}$ & 31.25 & 9.38 & 40.62 & 18.75 & 71.88 \\
\hline$t R N A^{T h r}$ & 36.92 & 10.77 & 41.54 & 10.77 & 78.46 \\
\hline$t R N A^{\text {Pro }}$ & 35.29 & 8.82 & 41.18 & 14.71 & 76.47 \\
\hline$t R N A^{\operatorname{Ser}(U C N)}$ & 40.30 & 16.42 & 37.31 & 5.97 & 77.61 \\
\hline tRNA $A^{\text {Leu }(C U N)}$ & 39.13 & 8.70 & 37.68 & 14.49 & 76.81 \\
\hline tRNA $A^{\text {Val }}$ & 28.38 & 14.86 & 37.84 & 18.92 & 66.22 \\
\hline$t R N A^{I l e}$ & 34.33 & 17.91 & 38.81 & 8.96 & 73.13 \\
\hline$t R N A^{G I n}$ & 33.33 & 10.14 & 33.33 & 23.19 & 66.67 \\
\hline$t R N A^{M e t}$ & 34.78 & 13.04 & 30.43 & 21.74 & 65.22 \\
\hline$t R N A^{T r p}$ & 46.27 & 10.45 & 28.36 & 14.93 & 74.63 \\
\hline$t R N A^{C y s}$ & 32.31 & 10.77 & 38.46 & 18.46 & 70.77 \\
\hline$t R N A^{T y r}$ & 31.82 & 13.64 & 34.85 & 19.70 & 66.67 \\
\hline \multicolumn{6}{|l|}{ rRNA genes } \\
\hline $16 S r R N A$ & 35.79 & 10.98 & 37.52 & 15.71 & 73.31 \\
\hline $12 S r R N A$ & 33.81 & 11.35 & 35.82 & 19.03 & 69.62 \\
\hline Control region & 42.09 & 9.80 & 34.14 & 13.98 & 76.22 \\
\hline Overall of protein-coding & 32.23 & 12.66 & 34.56 & 20.55 & 66.79 \\
\hline Overall of tRNA genes & 35.31 & 13.29 & 36.26 & 15.13 & 71.57 \\
\hline Overall of rRNA genes & 35.02 & 11.12 & 36.86 & 17.00 & 71.88 \\
\hline Overall of the genome & 33.63 & 12.24 & 35.09 & 19.04 & 68.72 \\
\hline
\end{tabular}

$*$ Genes that were encoded by the light strand were converted to complementary strand sequences. tRNA $=$ transfer RNA; rRNA = ribosomal RNA. 


\section{Phylogenetic relationships}

A phylogenetic tree was constructed based on 12 concatenated protein-coding genes from the mitochondrial genomes of 23 species (Figure 3). We estimated the evolutionary relationships of $P$. pelagicus within the Decapoda, and found that $P$. pelagicus and $P$. trituberculatus first clustered together and were the most closely related. They formed a monophyletic group with $C$. sapidus, and then clustered with another group formed by $C$. feriata, C. japonica, and Thalamita crenata. These species had a sister relationship with another four species of the genus Scylla. Therefore, our results support the inclusion of Charybdis in subfamily Portuninae of the family Portunidae, as proposed by Liu and Cui (2010).

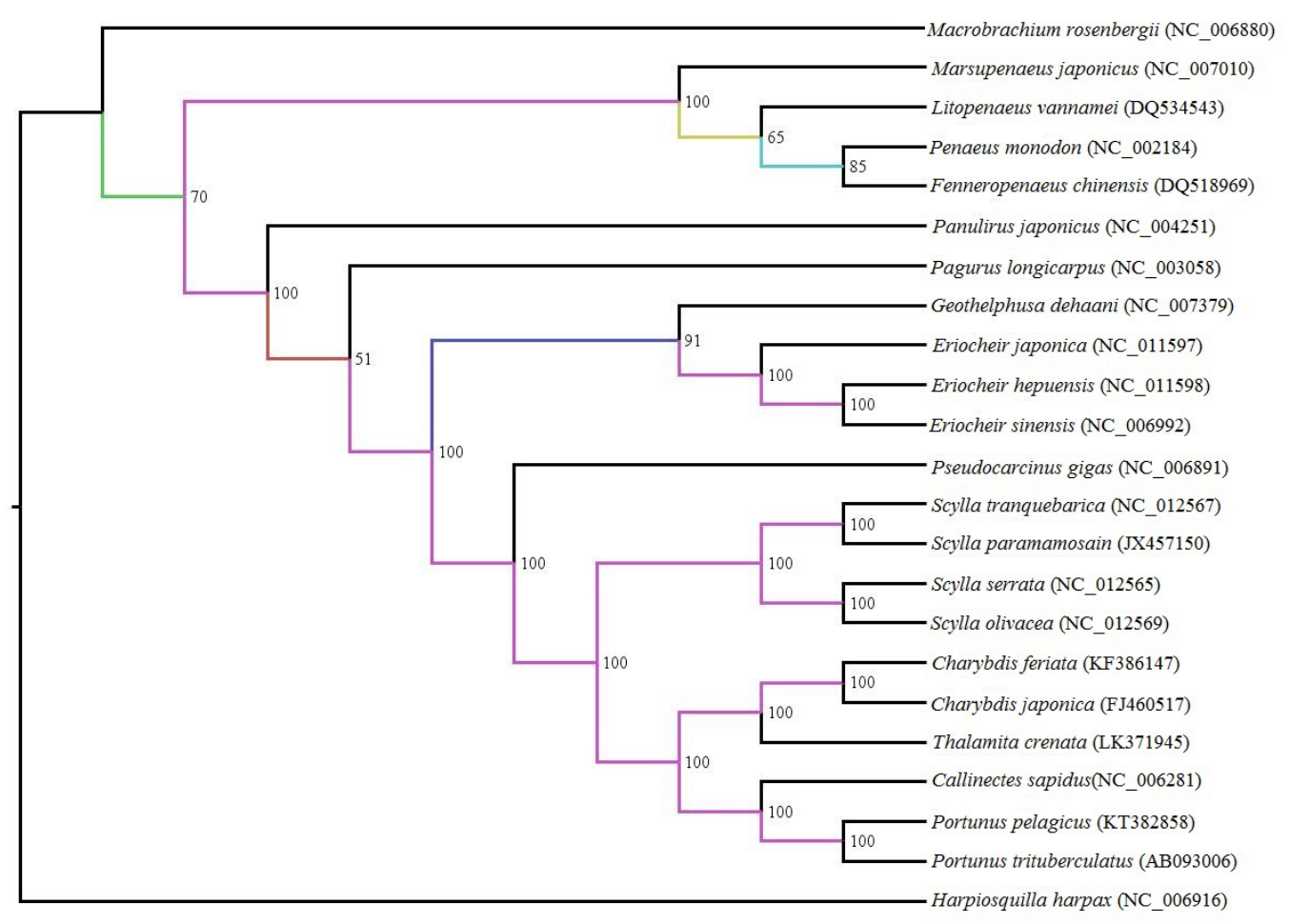

Figure 3. Phylogenetic relationships of Decapoda species based on 12 protein-coding.

\section{CONCLUSIONS}

We described the complete mitochondrial genome of P. pelagicus, which was 16,155 bp in length and contained 37 genes and a control region. Phylogenetic analysis based on 12 concatenated protein-coding genes supported the inclusion of Charybdis in subfamily Portuninae of the family Portunidae, and revealed a close relationship between Charybdis and Thalamita. We suggest that Thalamita should also be classified into the subfamily Portuninae. The results of this study can be used in phylogenetic, population genetic, and conservation genetic studies of $P$. pelagicus.

Genetics and Molecular Research 15 (3): gmr.15038719 


\section{Conflicts of interest}

The authors declare no conflict of interest.

\section{ACKNOWLEDGMENTS}

Research supported by the National Basic Research Special Foundation of China (Grant \#2013FY110700), the National Science and Technology Support Plan (Grant \#2013BAD13B05), the National Program for Support of Top-Notch Young Professionals, and the National Infrastructure of Fishery Germplasm Resources.

\section{REFERENCES}

Andrés M, Rotllant G and Zeng C (2010). Survival, development and growth of larvae of the blue swimmer crab, Portunus pelagicus, cultured under different photoperiod conditions. Aquaculture 300: 218-222 http://dx.doi.org/10.1016/j. aquaculture.2009.12.026.

Baek SY, Choi EH, Jang KH, Ryu SH, et al. (2014). Complete mitochondrial genomes of Carcinoscorpius rotundicauda and Tachypleus tridentatus (Xiphosura, Arthropoda) and implications for chelicerate phylogenetic studies. Int. J. Biol. Sci. 10: 479-489 http://dx.doi.org/10.7150/ijbs.8739.

Bryars SR and Adams M (1999). An allozyme study of the blue swimming crab, Portunus pelagicus (Crustacea: Portunidae), in Australia: stock delineation in southern Australia and evidence for a cryptic species in northern waters. Mar. Freshw. Res. 50: 15-26. http://dx.doi.org/10.1071/MF98075

Bryars SR and Havenhand JN (2006). Effects of constant and varying temperatures on the development of blue swimmer crab (Portunus pelagicus) larvae: laboratory observations and field predictions for temperate coastal waters. J. Exp. Mar. Biol. Ecol. 329: 218-229 http://dx.doi.org/10.1016/j.jembe.2005.09.004.

Jondeung A, Karinthanyakit W and Kaewkhumsan J (2012). The complete mitochondrial genome of the black mud crab, Scylla serrata (Crustacea: Brachyura: Portunidae) and its phylogenetic position among (pan)crustaceans. Mol. Biol. Rep. 39: 10921-10937 http://dx.doi.org/10.1007\%2Fs11033-012-1992-2. http://dx.doi.org/10.1007/s11033-012$\underline{1992-2}$

Josileen J and Menon NG (2004). Larval stages of the blue swimmer crab, Portunus pelagicus (Linnaeus, 1758) (Decapoda, Brachyura). Crustaceana 77: 785-803. http://dx.doi.org/10.1163/156854004774248681

Kailola PJ, Williams MJ, Stewart PC, Reichelt RE, et al. (1993). Australian fisheries resources. Bureau of Resource Sciences, Department of Primary Industries and Energy, and the Fisheries Research and Development Corporation, Canberra, Australia, 422.

Klinbunga S, Yuvanatemiya V, Wongphayak S, Khetpu K, et al. (2010). Genetic population differentiation of the blue swimming crab Portunus pelagicus (Portunidae) in Thai waters revealed by RAPD analysis. Genet. Mol. Res. 9: 1615-1624. http://dx.doi.org/10.4238/vol9-3gmr886

Knudsen B, Kohn AB, Nahir B, McFadden CS, et al. (2006). Complete DNA sequence of the mitochondrial genome of the sea-slug, Aplysia californica: conservation of the gene order in Euthyneura. Mol. Phylogenet. Evol. 38: 459-469 http://dx.doi.org/10.1016/j.ympev.2005.08.017.

Kumar S, Nei M, Dudley J and Tamura K (2008). MEGA: a biologist-centric software for evolutionary analysis of DNA and protein sequences. Brief. Bioinform. 9: 299-306. http://dx.doi.org/10.1093/bib/bbn017

Lai J, Ng PKL and Davie PJF (2010). A revision of the Portunus pelagicus (Linnaeus, 1758) species complex (Crustacea: Brachyura: Portunidae), with the recognition of four species. Raffles Bull. Zool. 58: 199-237.

Liu Y and Cui Z (2010). Complete mitochondrial genome of the Asian paddle crab Charybdis japonica (Crustacea: Decapoda: Portunidae): gene rearrangement of the marine brachyurans and phylogenetic considerations of the decapods. Mol. Biol. Rep. 37: 2559-2569 http://dx.doi.org/10.1007/s11033-009-9773-2.

Lohse M, Drechsel O and Bock R (2007). OrganellarGenomeDRAW (OGDRAW): a tool for the easy generation of high-quality custom graphical maps of plastid and mitochondrial genomes. Curr. Genet. 52: 267-274 http://dx.doi. org/10.1007/s00294-007-0161-y.

Lowe TM and Eddy SR (1997). tRNAscan-SE: a program for improved detection of transfer RNA genes in genomic sequence. Nucleic Acids Res. 25: 955-964. http://dx.doi.org/10.1093/nar/25.5.0955

Genetics and Molecular Research 15 (3): gmr.15038719 
Ma H, Ma C, Li X, Xu Z, et al. (2013). The complete mitochondrial genome sequence and gene organization of the mud crab (Scylla paramamosain) with phylogenetic consideration. Gene 519: 120-127 http://dx.doi.org/10.1016/j. gene.2013.01.028.

Ma H, Ma C, Li C, Lu J, et al. (2015). First mitochondrial genome for the red crab (Charybdis feriata) with implication of phylogenomics and population genetics. Sci. Rep. 5: 11524. http://dx.doi.org/10.1038/srep11524

Ma HY, Yang JF, Su PZ and Chen SL (2009). Genetic analysis of gynogenetic and common populations of Verasper moseri using SSR markers. Wuhan Univ. J. Nat. Sci. 14: 267-273. http://dx.doi.org/10.1007/s11859-009-0315-5

Miya M and Nishida M (2000). Use of mitogenomic information in teleostean molecular phylogenetics: a tree-based exploration under the maximum-parsimony optimality criterion. Mol. Phylogenet. Evol. 17: 437-455 http://dx.doi. org/10.1006/mpev.2000.0839.

Ojala D, Montoya J and Attardi G (1981). tRNA punctuation model of RNA processing in human mitochondria. Nature 290: 470-474. http://dx.doi.org/10.1038/290470a0

Praipue P, Klinbunga S and Jarayabhand P (2010). Genetic diversity of wild and domesticated stocks of Thai abalone, Haliotis asinina (Haliotidae), analyzed by single-strand conformational polymorphism of AFLP-derived markers. Genet. Mol. Res. 9: 1136-1152. http://dx.doi.org/10.4238/vol9-2gmr808

Romano N and Zeng C (2007a). Ontogenetic changes in tolerance to acute ammonia exposure and associated histological alterations of the gill structure through the early juvenile development of the blue swimmer crab, Portunus pelagicus. Aquaculture 266: 246-254. http://dx.doi.org/10.1016/j.aquaculture.2007.01.035

Romano N and Zeng C (2007b). Effects of potassium on nitrate mediated alterations of osmoregulation in marine crabs. Aquat. Toxicol. 85: 202-208. http://dx.doi.org/10.1016/j.aquatox.2007.09.004

Romano N and Zeng C (2007c). Acute toxicity of sodium nitrate, potassium nitrate, and potassium chloride and their effects on the hemolymph composition and gill structure of early juvenile blue swimmer crabs(Portunus pelagicus Linnaeus, 1758) (Decapoda, Brachyura, Portunidae). Environ. Toxicol. Chem. 26: 1955-1962 http://dx.doi.org/10.1897/07144R.1.

Romano N and Zeng C (2008). Blue swimmer crabs- emerging species in Asia. Global Aq. Adv. 11: 34-36.

Sezmis E (2004). The population genetic structure of Portunus pelagicus in Australian waters. PhD thesis, Murdoch University, Perth.

Shen X, Ren J, Cui Z, Sha Z, et al. (2007). The complete mitochondrial genomes of two common shrimps (Litopenaeus vannamei and Fenneropenaeus chinensis) and their phylogenomic considerations. Gene 403: 98-109 http://dx.doi. org/10.1016/j.gene.2007.06.021.

Stamatakis A, Hoover P and Rougemont J (2008). A rapid bootstrap algorithm for the RAxML Web servers. Syst. Biol. 57: 758-771 http://dx.doi.org/10.1080/10635150802429642.

Wang QR, Xu C, Xu CR and Wang RJ (2015). Complete mitochondrial genome of the Southern catfish (Silurus meridionalis Chen) and Chinese catfish (S. asotus Linnaeus): Structure, phylogeny, and intraspecific variation. Genet. Mol. Res. 14: 18198-18209. http://dx.doi.org/10.4238/2015.December.23.7

Wang Y, Liu X and Yang D (2014). The first mitochondrial genome for caddisfly (insecta: Trichoptera) with phylogenetic implications. Int. J. Biol. Sci. 10: 53-63 http://dx.doi.org/10.7150/ijbs.7975.

Yamauchi MM, Miya MU and Nishida M (2003). Complete mitochondrial DNA sequence of the swimming crab, Portunus trituberculatus (Crustacea: Decapoda: Brachyura). Gene 311: 129-135 http://dx.doi.org/10.1016/S0378$1119(03) 00582-1$.

Yan Y, Wang Y, Liu X, Winterton SL, et al. (2014). The first mitochondrial genomes of antlion (Neuroptera: Myrmeleontidae) and split-footed lacewing (Neuroptera: Nymphidae), with phylogenetic implications of Myrmeleontiformia. Int. J. Biol. Sci. 10: 895-908 http://dx.doi.org/10.7150/ijbs.9454.

Yu JN, Azuma N and Abe S (2012). Genetic differentiation between collections of hatchery and wild masu salmon (Oncorhynchus masou) inferred from mitochondrial and microsatellite DNA analysis. Environ. Biol. Fishes 94: 259$271 \mathrm{http}: / / \mathrm{dx}$. doi.org/10.1007/s10641-011-9869-0.

Zairion YW, Wardiatno Y, Boer M and Fahrudin A (2015). Reproductive biology of the blue swimming crab Portunus pelagicus (Brachyura: Portunidae) in East Lampung waters, Indonesia: fecundity and reproductive potential. Trop. Life Sci. Res. 26: 67-85.

Genetics and Molecular Research 15 (3): gmr.15038719 